\title{
Determination of Heavy Metals in Freshwater Fishes of the Tigris River in Baghdad
}

\author{
Montazer Mensoor ${ }^{1, *(1)}$ and Ali Said ${ }^{2}$ \\ 1 International Center for Training, Research \& Development, Baghdad 10069, Iraq \\ 2 Department of Pharmacy, Al-Yarmouk University College, Baghdad 10069, Iraq; alidubuni@yahoo.com \\ * Correspondence: montazerkamel@gmail.com; Tel.: +1-571-522-4352
}

Received: 23 May 2018; Accepted: 11 June 2018; Published: 13 June 2018

check for updates

\begin{abstract}
The presence of heavy metals in freshwater fish represents a global public health issue. The current study aimed to determine the heavy metal concentration and toxicity in some freshwater fish species collected from the Tigris River in Baghdad. Out of the many fish species in Iraq, the current study selected the Genus Barbus as it represents the most popular fish food in Iraq. The sample included twenty fishes and the selected sample locations covered two industrial areas in Baghdad (one north of Baghdad and one south of Baghdad). The levels of heavy metals were determined by using an atomic absorption spectrophotometer (AAS). The results showed that concentrations of heavy metals in the sampled fishes exceeded the acceptable levels for food sources for human consumption. The results of this study showed high levels of cadmium and chromium levels in the tissues of the selected fish sample. $\mathrm{Cd}$ and $\mathrm{Cr}$ were among the highest concentrations and both exceeded the World Health Organization and Food and Agriculture Organization of the United Nations acceptable levels for heavy metals in fishes.
\end{abstract}

Keywords: heavy metals; freshwater fishes; Tigris; Baghdad

\section{Introduction}

The pollution of the Tigris River with chemicals or hazardous materials has long been a very serious environmental problem and a major public health issue in Iraq [1-6]. Moreover, in recent years, there has been a special increasing interest in heavy metal contamination and toxicity in aquatic biomes [7]. Rivers could be contaminated by heavy metals as a result of industrial and agricultural waste and by-products. High concentrations of these heavy metals are toxic to the water, soil, and air. Fishes in the Tigris River are an important food source for the population. The Barbus species in Iraq are among the most common fish eaten as food [8]. Furthermore, fish play key roles in ecosystems because they are vertebrates, which are at the top of the food chain [9]. In recent years, the Tigris River has become heavily polluted and contaminated with different types of pollutants. Among other contaminants, heavy metals represent the most dangerous type of pollution as it has been well documented that heavy metals, such as arsenic, cadmium, chromium, lead, and copper are highly toxic to human cells [10].

Over the last twenty years, increased agricultural, industrial, and other anthropogenic activities along the Tigris River in Baghdad have resulted in increased heavy metal accumulation in the river. Consequently, high levels of heavy metals could lead to an ecological and health disaster [11]. The accumulation of heavy metals in freshwater fish depends on many factors. These factors can be either environmental (water chemistry, salinity, temperature, and levels of contamination) or biological (species, size, age, gender, sexual maturity, and diet) [12].

When comparing the accumulation of heavy metals in fishes of both marine and freshwater biomes, it can be observed that freshwater fishes tend to accumulate heavy metals in their organs 
more than marine fishes. The reason for such a difference between the two biomes is that freshwater fishes tend to lose salts and gain water. On the other hand, marine fishes tend to gain salts and lose water. Consequently, freshwater fishes are more exposed and vulnerable to heavy metal pollution [13]. Heavy metals are specifically important due to their toxicity and ability to bioaccumulate in aquatic biomes [14]. Heavy metals tend to accumulate in the aquatic environment because they cannot be degraded. Ultimately, this leads to human exposure and results in serious environmental problems [15]. The aim of the current study was to determine the levels of heavy metals $(\mathrm{Cd}, \mathrm{Cr}, \mathrm{Cu}, \mathrm{Pb}$, and $\mathrm{Zn})$ in the gills, livers, and muscles of Barbus sharpeyi and Barbus xanthopterus caught from the Tigris River in Baghdad. Understanding the concentrations of heavy metals in freshwater fishes in the Tigris River in Baghdad will help us to understand the risks of heavy metals contamination on human health. Thus, we will be able to establish practical and cost effective remediations for this environmental and public health problem.

\section{Results}

The results of heavy metal concentration ( $\mu \mathrm{g} / \mathrm{g}$ per wet weight) analyses in the gills, livers, and muscles of B. sharpeyi and B. xanthopterus at Station 1 and Station 2 are shown in Tables 1-3. Table 1 shows heavy metal concentrations in the gills of B. sharpeyi and B. xanthopterus at Station 1 (Al-Kadhimiya area) and Station 2 (Zafaraniya area). High concentrations of $\mathrm{Cd}, \mathrm{Cr}, \mathrm{Pb}, \mathrm{Zn}$, and $\mathrm{Cu}$ were detected in the gills of $B$. sharpeyi and B. xanthopterus in both areas. $\mathrm{Cd}$ had a higher concentration than the rest of the heavy metals that were found in the sample. The heavy metal concentrations in the gills of B. sharpeyi and B. xanthopterus in Station 1 (Al-Kadhimiya area) and Station 2 (Zafaraniya area) were distributed according to the following pattern: $\mathrm{Cd}>\mathrm{Cr}>\mathrm{Pb}>\mathrm{Zn}>\mathrm{Cu}$. The heavy metal concentrations in the livers of B. sharpeyi and B. xanthopterus at Station 1 (Al-Kadhimiya area) and Station 2 (Zafaraniya area) (Table 2) were distributed according to the following pattern: $\mathrm{Cd}>\mathrm{Cr}>$ $\mathrm{Pb}>\mathrm{Zn}>\mathrm{Cu}$. The heavy metal concentrations in the muscles of B. sharpeyi and B. xanthopterus at Station 1 (Al-Kadhimiya area) and Station 2 (Zafaraniya area) (Table 3) were distributed according to the following sequence: $\mathrm{Cd}>\mathrm{Cr}>\mathrm{Pb}>\mathrm{Cu}>\mathrm{Zn}$.

Table 1. Mean concentrations of heavy metals $(\mu \mathrm{g} / \mathrm{g})$ in the gills of Barbus sharpeyi and Barbus xanthopterus at Station 1 and Station 2.

\begin{tabular}{ccccc}
\hline Heavy Metals & $\begin{array}{c}\text { B. sharpeyi at } \\
\text { Station 1 }\end{array}$ & $\begin{array}{c}\text { B. xanthopterus at } \\
\text { Station 1 }\end{array}$ & $\begin{array}{c}\text { B. sharpeyi at } \\
\text { Station 2 }\end{array}$ & $\begin{array}{c}\text { B. xanthopterus at } \\
\text { Station 2 }\end{array}$ \\
\hline $\mathrm{Cd}$ & $2.30 \pm 0.15$ & $2.20 \pm 0.20$ & $2.40 \pm 0.15$ & $2.50 \pm 0.20$ \\
$\mathrm{Cr}$ & $2.20 \pm 0.40$ & $2.10 \pm 0.40$ & $2.50 \pm 0.40$ & $2.50 \pm 0.40$ \\
$\mathrm{~Pb}$ & $1.50 \pm 0.30$ & $1.30 \pm 0.30$ & $1.60 \pm 0.30$ & $1.60 \pm 0.40$ \\
$\mathrm{Zn}$ & $1.05 \pm 0.12$ & $1.10 \pm 0.40$ & $1.10 \pm 0.30$ & $1.20 \pm 0.30$ \\
$\mathrm{Cu}$ & $1.10 \pm 0.30$ & $1.20 \pm 0.30$ & $1.20 \pm 0.30$ & $1.30 \pm 0.30$ \\
\hline
\end{tabular}

Table 2. Mean concentrations of heavy metals ( $\mu \mathrm{g} / \mathrm{g})$ in the livers of B. sharpeyi and B. xanthopterus at Station 1 and Station 2.

\begin{tabular}{ccccc}
\hline Heavy Metals & $\begin{array}{c}\text { B. sharpeyi at } \\
\text { Station 1 }\end{array}$ & $\begin{array}{c}\text { B. xanthopterus at } \\
\text { Station 1 }\end{array}$ & $\begin{array}{c}\text { B. sharpeyi at } \\
\text { Station 2 }\end{array}$ & $\begin{array}{c}\text { B. xanthopterus at } \\
\text { Station 2 }\end{array}$ \\
\hline $\mathrm{Cd}$ & $1.30 \pm 0.30$ & $2.70 \pm 0.80$ & $2.90 \pm 0.80$ & $2.80 \pm 0.70$ \\
$\mathrm{Cr}$ & $2.50 \pm 1.10$ & $2.20 \pm 0.70$ & $2.70 \pm 0.70$ & $2.60 \pm 0.50$ \\
$\mathrm{~Pb}$ & $2.05 \pm 0.30$ & $1.80 \pm 0.50$ & $2.05 \pm 0.40$ & $2.10 \pm 0.50$ \\
$\mathrm{Zn}$ & $0.90 \pm 0.10$ & $0.70 \pm 0.20$ & $0.90 \pm 0.10$ & $0.90 \pm 0.20$ \\
$\mathrm{Cu}$ & $0.50 \pm 0.20$ & $0.70 \pm 0.30$ & $0.80 \pm 0.20$ & $0.80 \pm 0.20$ \\
\hline
\end{tabular}


Table 3. Mean concentrations of heavy metals $(\mu \mathrm{g} / \mathrm{g})$ in the muscles of B. sharpeyi and B. xanthopterus at Station 1 and Station 2.

\begin{tabular}{ccccc}
\hline Heavy metals & $\begin{array}{c}\text { B. sharpeyi at } \\
\text { Station 1 }\end{array}$ & $\begin{array}{c}\text { B. xanthopterus at } \\
\text { Station 1 }\end{array}$ & $\begin{array}{c}\text { B. sharpeyi at } \\
\text { Station 2 }\end{array}$ & $\begin{array}{c}\text { B. xanthopterus at } \\
\text { Station 2 }\end{array}$ \\
\hline $\mathrm{Cd}$ & $1.20 \pm 0.30$ & $0.80 \pm 0.20$ & $0.97 \pm 0.12$ & $0.80 \pm 0.10$ \\
$\mathrm{Cr}$ & $0.60 \pm 0.20$ & $0.50 \pm 0.20$ & $1.60 \pm 0.20$ & $1.60 \pm 0.20$ \\
$\mathrm{~Pb}$ & $1.05 \pm 0.40$ & $1.10 \pm 0.60$ & $1.05 \pm 0.50$ & $1.10 \pm 0.60$ \\
$\mathrm{Zn}$ & $0.80 \pm 0.20$ & $0.70 \pm 0.30$ & $0.80 \pm 0.20$ & $0.80 \pm 0.20$ \\
$\mathrm{Cu}$ & $0.60 \pm 0.20$ & $0.70 \pm 0.40$ & $0.70 \pm 0.20$ & $0.80 \pm 0.20$ \\
\hline
\end{tabular}

\section{Discussion}

It was assumed that the second sampling station (Zafaraniya) would have the highest heavy metal concentration since this area was heavily populated and the river in this area is likely to receive more industrial pollutants and effluents. However, the first station (Kadhimiya) also showed higher levels of heavy metal pollution. However, the concentrations of heavy metals in the gills, livers, and muscles of the sampled fish caught from the second station (Zafaraniya) were slightly higher than those obtained from the first station (Kadhimiya). The results of this study showed that the highest heavy metal concentrations were found in the gills and livers of both sampled fishes. These results are similar to other studies that showed the bioaccumulation of heavy metals in the gills and livers of fishes was higher than the concentrations of heavy metals in the muscles of fishes [16-18].

The mean concentrations of heavy metals in the gills, livers, and muscles of both fish samples (B. sharpeyi and B. xanthopterus) at both locations (Station 1: Kadhimiya and Station 2: Zafaraniya) were much higher than the World Health Organization (WHO) and Food and Agriculture Organization of the United Nations (FAO) maximum permissible levels of heavy metals in freshwater fishes [19-22]. The maximum permissible limit of heavy metals in freshwater fishes according to the WHO and FAO standards for $\mathrm{Cd}$ and $\mathrm{Cr}$ is $0.05 \mu \mathrm{g} / \mathrm{g}[19,21]$. Water pollution can cause fish to be contaminated with heavy metals from domestic and industrial anthropogenic activities [23]. Different levels of $\mathrm{Cd}, \mathrm{Cr}, \mathrm{Cu}$, $\mathrm{Pb}$, and $\mathrm{Zn}$ were seen in the gills, livers, and muscles of B. sharpeyi and B. xanthopterus in the Tigris River in the areas of Zafaraniya and Kadhimiya (Tables 1-3). The concentration of $\mathrm{Cd}$ in the gills at both stations varied from $2.20 \mu \mathrm{g} / \mathrm{g}$ to $2.50 \mu \mathrm{g} / \mathrm{g}$, while the concentration of $\mathrm{Cd}$ in the livers at both stations was $1.30 \mu \mathrm{g} / \mathrm{g}$ to $2.90 \mu \mathrm{g} / \mathrm{g}$. The muscles of B. sharpeyi and B. xanthopterus at both stations had the lowest $C d$ concentrations, ranging from $0.80 \mu \mathrm{g} / \mathrm{g}$ to $1.20 \mu \mathrm{g} / \mathrm{g}$. The high concentration of heavy metals in the gills of B. sharpeyi and B. xanthopterus was due to the fact that the gills in freshwater fishes are the main entry point for any dissolved heavy metals [18].

The concentration of $\mathrm{Cr}$ in the gills of B. sharpeyi was $2.20 \mu \mathrm{g} / \mathrm{g}$ at Station 1 (Kadhimiya) and $2.50 \mu \mathrm{g} / \mathrm{g}$ at Station 2 (Zafaraniya). For B. xanthopterus, the Cr concentration in the gills was $2.10 \mu \mathrm{g} / \mathrm{g}$ at Station 1 and 2.50 at Station 2. The livers and muscles also had high levels of $\mathrm{Cr}$, but lower levels than those detected in the gills. One of the reasons for such high concentrations in the gills, livers, and muscles of the sampled fishes was the recent prevalence of dyeing and tanning factories in Baghdad. Most of these local factories use chromium salts in their tanning processes [5]. As a result, and with the absence of effective waste management, the Tigris River is heavily polluted with chromium. Furthermore, chromium is used in painting, cooling tower drainage, and in the glass and ceramics industry. Power plants in Baghdad also use chromium salts, and chromite would be a by-product released from the waste of glass and ceramics industries in Baghdad. The results of this study regarding the levels of $\mathrm{Cr}$ in the Tigris River conform to results obtained by other studies [5,24-26]. The second station (Zafaraniya) showed higher levels of heavy metals detected in fish tissues than the first station (Kadhimiya). The second station (Zafaraniya) is considered to be the largest local industrial area in Baghdad. In this area, many different industrial factories are located, and they discharge their wastes into the river without proper treatment. The results of this study showed higher levels of $\mathrm{Cd}$ in the gills, livers, and muscles of B. sharpeyi and B. xanthopterus in the Tigris River. These results are similar 
to other studies $[4,6,27,28]$. The mean concentrations of $\mathrm{Pb}, \mathrm{Zn}$, and $\mathrm{Cu}$ in the gills, livers, and muscles of B. sharpeyi and B. xanthopterus in the Tigris River in the areas of Zafaraniya and Kadhimiya were very high and the concentrations varied between the gills, livers, and muscles. The reasons for such increased levels of heavy metals in the sampled fishes were due to the industrial effluents discharged from the untreated wastes of factories located along the Tigris River in Baghdad. Different studies that have been conducted in Iraq have shown similar results [5-7,29-31].

\section{Materials and Methods}

\subsection{Sample Collection and Preparation}

A total of 20 fish, belonging to the species (B. sharpeyi and B. xanthopterus) was purchased (10 B. sharpeyi and 10 B. xanthopterus) from local fishermen at the river banks of the two sampling collection sites used for this study. The sampling sites selected for this study were Al-Kadhimiya (labeled as Station 1, latitude $33^{\circ} 22^{\prime} 36^{\prime \prime} \mathrm{N}$ and longitude $44^{\circ} 20^{\prime} 14^{\prime \prime} \mathrm{E}$ ) in the north of Baghdad and the second sampling station was the industrial area at Al-Zafaraniya (labeled as Station 2, latitude $33^{\circ} 15^{\prime} 2^{\prime \prime} \mathrm{N}$ and longitude $44^{\circ} 28^{\prime} 58^{\prime \prime} \mathrm{E}$ ) in the south of Baghdad. The study was conducted from October 2017 until February 2018. For B. sharpeyi, the mean weight was $1800 \mathrm{~g}$ and the mean length was $30.5 \mathrm{~cm}$. For B. xanthopterus, the mean weight was $2500 \mathrm{~g}$ and the mean length was $32 \mathrm{~cm}$. The collected samples were stored in a cooler packed with ice and were sent immediately to the laboratory for the dissection of the organs after removing the scales and washed thoroughly. Only the fish tissues (muscles, gills, and liver) were dried separately for $24 \mathrm{~h}$ to a constant weight in an oven at $105^{\circ} \mathrm{C}$. The various organs from each species collected were pooled and milled with a mortar and pestle. About one gram of the dried tissue was weighed and then transferred into polyethylene tubes, and $8 \mathrm{~mL}$ of nitric acid and $4 \mathrm{~mL}$ of perchloric acid were added to the sample. All standard solutions and chemicals that were used in the current study were obtained from Merck (Darmstadt, Germany), and all of them were of analytical grade. To avoid contamination, all bottles and glassware used in the preparation of the samples were soaked in nitric acid for $15 \mathrm{~min}$ and rinsed with deionized water before being used. The prepared sample was left overnight at room temperature. The sample was digested, and the digestion tubes were placed in a water bath set to a boiling temperature. The tubed sample was left to boil for an hour and a half until all tissues had been dissolved. Then, they were cooled, filtered, and placed in plastic bottles. Acidic digestion of the sample was done according to the procedures mentioned in [32], but the mineralization procedures were modified for the current study. The determination of heavy metals in the fish tissues was carried out using an atomic absorption spectrophotometer (Perkin-Elmer model 5000, Perkin-Elmer Corp, Waltham, MA, USA). The accuracy and precision were verified using standard reference materials (MA-A-2/TM) provided by the International Atomic Agency (IAEA) [33]. The absorption wavelengths and detection limits for the heavy metals were $228.8 \mathrm{~nm}(\mathrm{~nm}=$ wavelength) and $0.002 \mathrm{ppm}$ for $\mathrm{Cd} ; 425.4 \mathrm{~nm}$ and $0.002 \mathrm{for} \mathrm{Cr} ; 217.0 \mathrm{~nm}$ and $0.001 \mathrm{ppm}$ for $\mathrm{Pb} ; 213.9 \mathrm{~nm}$ and $0.001 \mathrm{ppm}$ for $\mathrm{Zn}$; and $324.7 \mathrm{~nm}$ and $0.02 \mathrm{ppm}$ for $\mathrm{Cu}$.

\subsection{Statistical Analysis}

The concentrations of metals in fish tissues were reported as $\mu \mathrm{g} / \mathrm{g}$ per wet weight. One way-ANOVAs and $t$-tests were used to evaluate differences between B. sharpeyi and B. xanthopterus. A $p$-value less than (0.05) was considered to be statistically significant. All statistical calculations were performed using Windows-based SPSS version 23 (IBM Corp. Released 2015. IBM SPSS Statistics for Windows, Version 23.0. Armonk, NY, USA: IBM Corp.).

\section{Conclusions}

The current study showed significant, high concentrations of heavy metals in fish tissues in the Tigris River in Baghdad. The high bioaccumulation level of heavy metals in fish tissues, especially in the gills and livers, presents a good bio-marker for monitoring heavy metal toxicity and water 
pollution in the Tigris River. Further research with a bigger sample of fish and greater area coverage in Baghdad is recommended to confirm these results. The presence of high concentrations of chromium in the Tigris River at Station 1 and Station 2 through this study requires further investigation in regard to the hexavalent chromium toxicity in freshwater fishes or sediments of the Tigris River in Baghdad.

Author Contributions: Conceptualization, M.M.; Methodology, M.M.; Software, M.M.; Validation, M.M., and A.S.; Formal Analysis, M.M.; Investigation, M.M.; Resources, M.M.; Data Curation, M.M.; Writing-Original Draft Preparation, M.M.; Writing-Review \& Editing, M.M. and A.S.; Visualization, M.M.; Supervision, M.M.; Project Administration, M.M.; Funding Acquisition, M.M.

Funding: This research received no external funding.

Conflicts of Interest: The authors declare no conflict of interest.

\section{References}

1. Al-Muhandis, M.H. Pollution of river water in Iraq. Hydro Sci. Publ. 1977, 123, 467-470.

2. AL-Layla, M.A.; AL-Rawi, S.M. Impact of Mosul textile factory effluents on Tigris River water quality. J. Environ. Sci. Health Part A 1988, 23, 559-568. [CrossRef]

3. Al-Lami, A.A.; Al-Jaberi, H.H. Heavy metals in water, suspended particles and sediment of the upper-mid region of Tigris River, Iraq. In Proceedings of the International Symposium on Environmental Pollution Control and Waste Management (EPCOWM'2002), Tunis, Tunisia, 7-10 January 2002; pp. 97-102.

4. Rabee, A.; Al-Fatlawi, Y.; Abd Own, A.N. Seasonal variation and assessment of heavy metals pollution in sediments from selected stations in Tigris and Euphrates Rivers, central Iraq. Iraqi J. Sci. 2009, 50, 466-475.

5. Al-Ubaidi, A.; Al-Janabi, Z.; Al-Kubaisi, A. Distribution of some heavy metals in Tigris River in Central Iraq. Baghdad J. Sci. 2014, 11, 983-990. (In Arabic)

6. Hassan, F.M.; Mahmood, A.R. Evaluate the efficiency of drinking water treatment plants in Baghdad City-Iraq. J. Appl. Environ. Microbiol. 2018, 6, 1-9.

7. Balasim, H.M.; Al-Azzawi, M.N.; Rabee, A.M. Assessment of pollution with some heavy metals in water, sediments and Barbus xanthopterus fish of the Tigris River-Iraq. Iraqi J. Sci. 2013, 54, 813-822.

8. Coad, B.W. Freshwater Fishes of Iraq, 1st ed.; Pensoft: Sofia, Bulgaria, 2010; pp. 86-89, ISBN 978-954-642-530-0.

9. Zaikov, G.E.; Weisfeld, L.I.; Bekuzarova, S.A.; Lisitsyn, E.M.; Opalko, A.I.; Haghi, A. Heavy Metals and Other Pollutants in the Environment: Biological Aspects, 1st ed.; Apple Academic Press: Oakville, ON, Canada, 2017; pp. 402-403, ISBN 9781315341804.

10. Gugala, N.; Turner, R.J. The potential of metals in combating bacterial pathogens. In Biomedical Applications of Metals, 1st ed.; Rai, M., Ingle, A., Medici, S., Eds.; Springer: Cham, Switzerland, 2018; pp. 129-150, ISBN 978-3-319-74813-9.

11. Freedman, B. Environmental Ecology: The Ecological Effects of Pollution, Disturbance, and Other Stresses, 2nd ed.; Academic Press Inc.: San Diego, CA, USA, 1995; pp. 62-91, ISBN 0-12-266542-2.

12. Kallel, A.; Ksibi, M.; Dhia, H.B.; Khélifi, N. (Eds.) Recent Advances in Environmental Science from the Euro-Mediterranean and Surrounding Regions. In Proceedings of the Euro-Mediterranean Conference for Environmental Integration (EMCEI-1), Sousse, Tunisia, 22-25 November 2017; Springer: Cham, Switzerland, 2017.

13. Nikinmaa, M. An Introduction to Aquatic Toxicology, 1st ed.; Academic Press: Cambridge, MA, USA, 2014; p. 24, ISBN 978-0-12-411574-3.

14. Miller, J.R.; Lechler, P.J.; Hudson-Edwards, K.A.; Macklin, M.G. Lead isotopic fingerprinting of heavy metal contamination, Rio Pilcomayo basin, Bolivia. Geochem. Explor. Environ. Anal. 2002, 2, 225-233. [CrossRef]

15. Donati, E.R. Heavy Metals in the Environment: Microorganisms and Bioremediation, 1st ed.; CRC Press: Boca Raton, FL, USA, 2018; ISBN 13 978-1-4987-4799-8.

16. Mohammadi, M.; Sary, A.A.; Khodadadi, M. Determination of heavy metals in two barbs, Barbus grypus and Barbus xanthopterus in Karoon and Dez Rivers, Khoozestan, Iran. Bull. Environ. Contam. Toxicol. 2011, 87, 158-162. [CrossRef] [PubMed]

17. Karadede-Akin, H.; Ünlü, E. Heavy metal concentrations in water, sediment, fish and some benthic organisms from Tigris River, Turkey. Environ. Monit. Assess. 2007, 131, 323-337. [CrossRef] [PubMed] 
18. Olsson, P.; Kling, P.; Hogstrand, C. Mechanisms of heavy metal accumulation and toxicity in fish. In Metal Metabolism in Aquatic Environments, 2nd ed.; Langston, W.J., Bebianno, M.J., Eds.; Springer Science \& Business Media: Berlin, Germany, 2013; Volume 7, pp. 321-338, ISBN 9781475727616.

19. World Health Organization (WHO). WHO Guidelines for Drinking Water Quality, 4th ed.; WHO Publications: Geneva, Switzerland, 2011; pp. 307-340, ISBN 9789241548151.

20. Codex Alimentarius Commission. Codex General Standard for Contaminants and Toxins in Food and Feed, revised ed.; CODEX STAN 193, 1995; FAO: Geneva, Switzerland, 2015.

21. Food and Agriculture Organization of the United Nations (FAO). Heavy Metals Regulations Legal Notice No. 66/200; FAO: Rome, Italy, 2003.

22. European Commission. Amending Regulation (EC) No 1881/2006 Setting Maximum Levels for Certain Contaminants in Foodstuffs; Official Journal of the European Union; European Law and Publications: Brussels, Belgium, 19 December 2006.

23. Sun, J.; Ji, Y.; Cai, F.; Li, J. Heavy metal removal through biosorptive pathways. In Advances in Water Treatment and Pollution Prevention, 1st ed.; Sharma, S.K., Sanghi, R., Eds.; Springer Science \& Business Media: Berlin, Germany, 2012; pp. 95-146, ISBN 978-94-007-4203-1.

24. Mustafa, M.; Jankeer, M. Quality difference between two locations on Tigris River within Mosul City. Rafid. J. Sci. 2007, 18, 111-123. (In Arabic)

25. Mahmood, R.; Alkhafaji, N. Distribution of heavy metals in parts of Diyala River, Iraq. Int. J. Sci. Res. 2016, 6, 879-884.

26. Al-Azzawi, M. Distribution and circulation of chromium and cadmium metals in Tigris river. Iraqi J. Sci. 2010, 51, 249-254.

27. Al-Saadi, H.A.; Al-Mayaly, E.K.; Hassian, D.M. Heavy Metals in Diyala and Tigris River Southern Baghdad City, Iraq. J. Al-Qadisiyia Pure Sci. 2002, 7, 52-58.

28. Al-Sarraj, I.; Jankeer, M.; Al-Rawi, S. Study of some heavy metal bioaccumulation in tissues and organs of three fish types collected from Tigris River in Mosul. Rafid. J. Sci. 2014, 25, 43-55.

29. Al-Zubaidi, H.A. Effect of heavy metals in wastewater effluents of textile factory-Hilla on the characteristics of Hilla River. J. Kerbala Univ. 2012, 10, 5-16.

30. Hussein, S.A.; Fahad, K.K. Monthly Variations in Heavy Metal Concentrations in Garraf Canal from Tigris River. Al-Noor Center for Studies. Available online: http:/ / alnoor.se/article.asp?id=25611 (accessed on 1 April 2018). (In Arabic)

31. Al-Khafaji, A.K. Detection the Pollution Status of Soils and Waters of Sawa Lake Area by Using Remote Sensing Techniques. Master's Thesis, University of Al-Muthanna, Samawah, Iraq, 2016.

32. Murtala, B.A.; Abdul, W.O.; Akinyemi, A.A. Bioaccumulation of heavy metals in fish (Hydrocynus forskahlii, Hyperopisus bebe occidentalis and Clarias gariepinus) organs in downstream Ogun coastal water, Nigeria. J. Agric. Sci. 2012, 4, 51. [CrossRef]

33. Zschunke, A. Reference Materials in Analytical Chemistry: A Guide for Selection and Use, illustrated ed.; Springer Science \& Business Media: Berlin, Germany, 2013; pp. 25-55, ISBN 3642569862, 9783642569869.

(c) 2018 by the authors. Licensee MDPI, Basel, Switzerland. This article is an open access article distributed under the terms and conditions of the Creative Commons Attribution (CC BY) license (http:/ / creativecommons.org/licenses/by/4.0/). 